\title{
SOSIALISASI KEWIRAUSAHAAN DALAM UPAYA PENINGKATAN UMKM DESA PALANGAN KECAMATAN KARANGBINANGUN KABUPATEN LAMONGAN
}

\author{
Moh. Muklis Sulaeman \\ Jurusan Manajemen, Fakutas Ekonomi, Universitas Islam Lamongan \\ J1. Veteran No.53A Lamongan \\ Muklis849@gmail.com,
}

\begin{abstract}
ABSTRAK
Seiring berkembangnya zaman dunia teknologi semakin berkembang, sehingga UMKM perekonomian masyarakat harus mengikuti alur perkembangan teknologi untuk mempertahankan eksistensi dalam menjalankan bisnis dan usaha, karena Sektor Usaha Mikro Kecil dan Menengah (UMKM) memiliki peran penting dalam mendorong pertumbuhan. perekonomian Indonesia. UMKM memiliki andil sebesar $85 \%$ dalam penyerapan tenaga kerja. Dalam suatu usaha dibutuhkan studi mengenai kelayakan dari usaha tersebut. Namun kenyataannya masyarakat hanya terfokus pada status kerja sebagai karyawan diperusahaan untuk mendapatkan penghasian. Karena itulah pengembangan masyarakat dengan metode sosialisasi penanaman jiwa kewirausahaan dan bisnis online dilakukan untuk membantu memotivasi masyarakat untuk menjalankan usaha mandiri. Pemberdayaan merujuk pada kemampuan seseorang, khususnya kelompok lemah untuk memiiki akses terhadap sumbersumber produktif yang memungkinkan mereka dapat meningkatkan pendapatannya dan berpartisipasi dalam proses pembangunan serta pengambilan keputusan. Hasil dari penelitian ini menunjukkan bahwa masyarakat Desa Palangan Kecamatan Karangbinangun memiliki potensi yang besar untuk mengembangkan perekonomian desa melalui UMKM. Faktor pendukung dalam pengembangan masyarakat di bidang ekonomi ini meliputi sumber daya alam dan sumber daya manusia yang melimpah serta partisipasi masyarakan yang cukup tinggi. Sedangkan faktor penghambatnya adalah keterbatasan modal, sarana dan prasarana.
\end{abstract}

Kata Kunci : UMKM, Kewirausahaan, Pengembangan Perekonomian.

\begin{abstract}
As the development of the technological age of the world is growing, so that the economy's MSME community must follow the path of technological development to maintain its existence in running businesses and businesses, because the Micro, Small and Medium Enterprises Sector (MSME) has an important role in driving growth. Indonesian economy. MSME have a share of $85 \%$ in employment. In a business study is needed about the feasibility of the business. But in reality the community is only focused on working status as employees in the company to get benefits. That is why community development with the method of promoting entrepreneurship spirit and online business is done to help motivate the community to run an independent business. Empowerment refers to the ability of people, especially weak groups to have access to productive resources that enable them to increase their income and participate in the development and decision-making process. The results of this study indicate that the community of Palangan Village, Karangbinangun District has great potential to develop the village economy through MSME. Supporting factors in community development in the economic sector include abundant natural and human resources as well as fairly high community participation. While the limiting factor is the limited capital, facilities and infrastructure.
\end{abstract}

Keywords: MSME, Entrepreneurship, Economic Development. 


\section{PENDAHULUAN}

Kondisi masyarakat saat ini semakin berkembang, terutama akibat kemajuan ilmu pengetahuan dan teknologi yang semakin maju. Akibatnya masalah-masalah yang dihadapi pun semakin kompleks, kemajuan ilmu pengetahuan dan teknologi ini berimbas pada berbagai aspek kehidupan, seperti agama, sosial, budaya, ekonomi, politik, dan sebagainya. Hal ini menunjukkan bahwa implementasi terhadap konsep pembangunan telah banyak merubah kondisi kehidupan masyarakat. Negara dan pembangunan merupakan dua unsur yang tidak dapat dipisahkan satu sama lain. Hal ini dikarenakan suatu negara agar dapat mempertahankan kehidupannya selalu melakukan pembangunan.

Pada sebagian komunitas, pembangunan telah mengantarkan mereka pada kehidupan yang lebih baik, sementara bagi komunitas lainnya pembangunan justru mengantarkan mereka pada kondisi yang menyengsarakan dimana angka pengangguran dan kemiskinan semakin bertambah. Pembangunan itu sendiri dapat dilakukan melalui beberapa aspek, seperti pembangunan ekonomi, pembangunan sosial dan budaya maupun pembangunan politik.Namun, permasalahan pembangunan yang sering terjadi adalah masalah pembangunan ekonomi. Sektor Usaha Mikro Kecil dan Menengah (UMKM) memiliki peran penting dalam mendorong pertumbuhan perekonomian Indonesia UMKM memberi sekitar 87\% kontribusi ke dalam sejumlah badan usaha di Indonesia dan memiliki andil sebesar $85 \%$ dalam penyerapan tenaga kerja.

Sejalan dengan semangat nawacita, pemerintah berupaya untuk meningkatkan produktivitas rakyat dan daya saing secara internasional, serta menumbuhkan kemandirian ekonomi dengan pemberatan sektor- sektor strategis ekonomi domestik. Dengan adanya sektor UMKM, pengangguran akibat angkatan kerja yang tidak terserap dalam dunia kerja menjadi berkurang. Sektor UMKM pun telah terbukti menjadi pilar perekonomian yang tangguh. Dalam perencanaan suatu usaha dibutuhkan studi mengenai kelayakan dari usaha tersebut.Untuk mendirikan UMKM juga dibutuhkan analisis kelayakan terkait faktor- faktor atau aspek yang dapat mempengaruhi kemungkinan berhasilnya (layaknya) pelaksana gagasan suatu usaha. Namun kenyataannya pemilik usaha hanya terfokus pada pendapatan dan keberlanjutan usahanya. Karena itulah pengembangan masyarakat dengan metode pendampingan sosial perlu dilakukan untuk membantu memecahkan persoalan yang sedang dihadapi. 
Pengembangan Masyarakat mengandung upaya untuk meningkatkan partisipasi dan rasa memiliki terhadap program yang dilaksanakan. Pemberdayaan merujuk pada kemampuan seseorang, khususnya kelompok lemah untuk memiiki akses terhadap sumber-sumber produktif yang memungkinkan mereka untuk dapat meningkatkan pendapatannya dan berpartisipasi dalam proses pembangunan serta pengambilan keputusan.

\section{METODE}

Pelaksanaan sosialisasi mengenai kewirausahaan dan pelatihan bisnis online bagi masyarakat Desa Palangan Kecamatan Karangbinangun dilaksanakan pada hari Kamis tanggal 1 Agustus 2019, dengan menggunakan beberapa alat dan bahan diantaranya:

1. Buku

2. Alat Tulis

3. Laptop

4. LCD Proyektor

5. Alat bantu stimulasi berupa gambar-gambar produk kreatif.

Sedangkan metode yang digunakan adalah:

1. Ceramah, yaitu untuk memaparkan materi kajian mengenai kewirausahaan, datadata perkembangan perekonomian dan hutang negara-negara di dunia, prinsip ekonomi dan bisnis, dan beberapa permasalahan yang meliputi penanaman jiwa kewirausahaan, bagaimana melakukan study kelayakan usaha serta bagaimana memulai dan mengembangkan usaha.

2. Tanya jawab, yaitu digunakan untuk merespon sejauh mana tingkat pemahaman masyarakat terhadap materi yang telah disampaikan.

3. Simulasi yaitu digunakan untuk memperlihatkan atau member contoh nyata mengenahi berbagai kegiatan UMKM. 


\section{HASIL DAN PEMBAHASAN}

Pelaksanaan pengabdian di Desa Palangan Kecamatan Karangbinangun dilaksanakan pada hari Kamis, 01 Agustus 2019 berjalan dengan baik dan lancar. Dan pengabdian ini ditujukan supaya bisa membangun perekonomian masyarakat sekitar. Pembangunan sendiri sering diartikan sebagai suatu usaha untuk meningkatkan kehidupan masyarakat ke arah yang lebih baik. Pembangunan sebagai rangkaian usaha mewujudkan pertumbuhan dan perubahan secara terencana dan sadar yang ditempuh oleh suatu Negara menuju modernitas dalam rangka pembinaan bangsa. Menurut (Sondang, 2003) terdapat 5 implikasi utama dari pembangunan:

1. Pembangunan berarti membangkitkan kemampuan optimal manusia baik individu maupun kelompok.

2. Pembangunan dapat diartikan sebagai bentuk dorongan untuk menumbuhkan kebersamaan dan kesejahteraan.

3. Pembangunan berarti menaruh kepercayaan kepada masyarakat untuk membangun dirinya sendiri sesuai dengan kemampuan yang ada padanya.

4. Pembangunan berarti membangkitkan kemampuan untuk membangun secara mandiri.

5. Pembangunan berarti mengurangi ketergantungan negara satu dengan negara yang lain yang menciptakan hubungan saling menghormati.

Pembangunan masyarakat dapat diartikan sebagai aktivitas yang dilakukan oleh masyarakat, dimana mereka mampu mengidentifikasikan kebutuhan dan masalah secara bersama (Zamhariri,2008). Menurut Graha Adi pembangunan masyarakat adalah kegiatan yang terencana untuk menciptakan kondisi-kondisi bagi kemajuan sosial ekonomi masyarakat dengan mneingkatkan partisipasi masyarakat (Graha Adi, 2008). Pembangunan sektor sosial ekonomi masyarakat perlu diwujudkan untuk meningkatkan kesejahteraan masyarakat, yang didukung oleh organisasi dan partisipasi masyarakat yang memiliki kapasitas, kapabilitas, dan kinerja yang secara terus menerus tumbuh dan berkembang dalam kehidupan masyarakat [8].Pembangunan masyarakat di wilayah pedesaan pada masa yang lalu mendasarkan pada azas pemerataan yang pada penerapannya diarahkan secara sektoral. Meskipun dana atau anggaran pembangunan pedesaan jumlahnya cukup besar, tetapi jika dibagi secara merata maka masing-masing 
desa memperoleh jumlah dana yang relatif kecil, sehingga pada pemanfaatannya kurang optimal. Namun terdapat pergeseran menuju paradigma pembangunan partisipasi pelaku pembangunan ekonomi masyarakat yang menuntut kerangka perencanaan pembangunan spasial atau tata ruang. Kebijakan ini harus dapat menjawab pertanyaan mendasar yang berkaitan dengan peningkatan partisipasi dan produktifitas masyarakat, yaitu sebagai berikut (Graha Adi, 2008):

1. Bagaimana dapat mendorong partisipasi masyarakat.

2. Bagaimana dapat menciptakan dan meningkatkan kegiatan perekonomian antar sektor di tingkat pedesaan.

3. Bagaimana dapat menyusun perencanaan dan program pembangunan yang dibutuhkan masyarakat pedesaan.

4. Bagaimana dengan mengaktualisasikan peran serta masyarakat yang telah lama melembaga di tengah tradisi masyarakat seperti gotong royong, rembug desa, dan sebagainya.

Pemberdayaan ekonomi masyarakat mengandung maksud pembangunan ekonomi sebagian besar masyarakat Indonesia sebagai agenda utama pembangunan nasional sehingga langkah-langkah yang nyata harus diupayakan agar pertumbuhan ekonomi masyarakat berlangsung dengan cepat. Dengan adanya pemberdayaan ekonomi masyarakat, maka diharapkan dapat meningkatkan kehidupan masyarakat kearah yang lebih baik. Kehidupan masyarakat yang lebih baikpada dasarnya meliputi kebutuhan hidup, kebutuhan harga diri, dan kebutuhan kebebasan. Oleh karena itu, para ahli ekonomi mengemukakan bahwa sasaran pemberdayaan ekonomi masyarakat yang harus mengutamakan keperluan mutlak, syarat minimum untuk memenuhi kebutuhan pokok serta kebutuhan dasar. Pemberdayaan menunjuk pada kemampuan seseorang khususnya kelompok masyarakat lemah untuk memiliki akses terhadap sumber-sumber produktif yang memungkinkan mereka dapat meningkatkan pendapatannya dan memperoleh barang maupun jasa yang diperlukan serta berpartisipasi dalam proses pembangunan dan pengambilan keputusan yang mempengaruhi mereka.

\section{Pendampingan Sosial}

Pendampingan sosial hadir sebagai agen perubahan yang turut terlibat dalam membantu memecahkan persoalan yang dihadapi oleh masyarakat. Dengan demikian 
pendampingan sosial dapat diartikan sebagai interaksi dinamis antara kelompok miskin dan pekerja sosial yang secara bersama menghadapi beragam tantangan seperti:

1. Merancang program perbaikan kehidupan sosial ekonomi.

2. Mobilisasi sumber daya setempat.

3. Memecahkan masalah sosial.

4. Menciptakan dan membuka akses bagi pemenuhan kebutuhan.

5. Menjalin kerjasama dengan berbagai pihak yang relevan dengan konsep pemberdayaan masyarakat.

Selain melakukan pendampingan dari pihak internal team KKN-BBM Unisla 2019, pendampingan juga dilakukan dari pihak eksternal yaitu menggandeng PT. Jafra, guna untuk melakukan pelatihan dan peningkatan skill dibidang beauty class and online bussines.

Berdasarkan evaluasi pelaksanaan kegiatan, dapat diidentifikasi factor pendukung dan factor penghambat dari kegiatan ini sehingga dapat berjalan dengan baik, antara lain yaitu dukungan penuh dari Kepala desa Palangan Kecamatan Karangbinangun yang bersedia diajak kerjasama dan mendukung program kegiatan pengabdian masyarakat, Peserta KKN-BBM Unisla 2019 yang membantu kelancaran kegiatan pengabdian, serta antusiasme masyarakat Desa Palangan Kecamatan Karangbinangun peserta sosialisasi pengabdian masyarakat. Sedangkan factor penghambat yaitu keterbatasan sarana dan prasarana dalam memberikan sosialisasi pada waktu pelaksanaan yaitu belum adanya praktek pembuatan produk-produk kreatif.

\section{SIMPULAN}

Beberapa kesimpulan yang didapatkan dari kegiatan sosialisasi kewirausahaan dan bisnis online yakni: Meningkatkan pengetahuan bagi peserta tentang menanamkan dan membangun jiwa wirausaha, cara melakukan studi kelayakan usaha serta cara memulai mengembangkan usaha yang dijalankan. Selain itu sosialisasi ini juga mengenalkan perkembangan teknologi media sosial seiring berkembangnya teknologi yang semakin canggih untuk dapat digunakan dalam pengembangan dan memasarkan produk atau jasa yang dihasilkan. 


\section{DAFTAR PUSTAKA}

Andini, Ully Hikmah, dkk. 2015. PemberdayaanEkonomi Masyarakat dari Desa Tertinggal Menuju Desa Tidak Tertinggal. Jurnal Administrasi Publik (JAP). Vol 2.No. 12.

Darwanto. 2013. Peningkatan Daya SaingUMKM Berbasis Inovasi dan Kreativitas.Jurnal Bisnis dan Ekonomi.Hal.142-149.Vol 20, No. 2.

Graha, Adi Nu. Pengembangan Masyarakat Pembangunan Melalui Pendampingan Sosial dalam Konsep Pemberdayaan di BidangEkonomi.Jurnal Ekonomi MODERNISASI.

Lantu, D.C., Triady. M.S., Utami, A.F., Ghazali, A.2016. Pengembangan Model PeningkatanDaya Saing UMKM di Indonesia: Validasi Kuantitatif Model. Jurnal ManajemenTeknologi. Vol 15 No. 1. Hal 77-93.

Lazurdi, R. F., Fitria, L., Bakar, A. 2014. ArtikelJurnal Imiah Analisis Kelayakan UsahaMobile Carwash di Kota Bandung.JurnalOnline Institut Teknologi Nasional.Vol. 01No. 03.

Murdani dkk., Pengembangan Ekonomi Masyarakat Melalui Usaha Mikro kecil Menenggah, Jurnal online Universitas Negeri Semarang. Vol 23 No.2 : Hal. $152-157$

Rintuh, Cornelisdan Miar. 2005. Kelembagaandan Ekonomi Rakyat. Yogyakarta: BPFE.

Siagian, Sondang P. 2003. Administrasi Pembangunan. Jakarta: PT. Bumi Aksara.Riharjo, Adisasmita. 2006. PembangunanPerdesaan dan Perkotaan. Yogyakarta.Graha Ilmu.

Suryana. 2006. Ekonomi Pembangunan: Problematika dan Pendekatan. Jakarta: PustakaPelajar.

Zamhariri. 2008. Pengembangan Masyarakat:Perspektif Pemberdayaan dan Pembangunan. Vol 4.No. 1. 